\title{
Spontaneous coronary artery dissection involving both coronary arteries in an individual with Loeys-Dietz syndrome
}

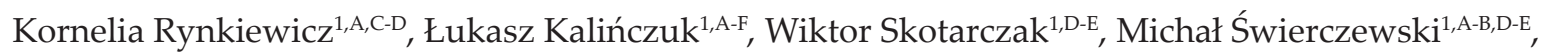 \\ Kamil Zieliński ${ }^{1, \mathrm{D}-\mathrm{E}}$, Rajmund Bobrowski ${ }^{1, \mathrm{E}}$, Ilona Michałowska ${ }^{2, \mathrm{E}}$, Zofia Bilińska ${ }^{3 \mathrm{E}}$, Marcin Demkow $^{1, \mathrm{~B}-\mathrm{C}, \mathrm{E}}$ \\ A - Research concept and design, B - Collection and/or assembly of data, C - Data analysis and interpretation, \\ D - Writing the article, E - Critical revision of the article, F - Final approval of article
}

1 Institute of Cardiology, Department of Coronary and Structural Heart Diseases

2 Department of Radiology, Institue of Cardiology Warsaw

3 Unit for Screening Studies in Inherited Cardiovascular Diseases Institute Cardiology Warsaw

\section{Address for correspondence:}

Łukasz Kalińczuk, Institute of Cardiology, Department of Coronary and Structural Heart Diseases email: lukasz.kalinczuk@gmail.com

Wiktor Skotarczak, Institute of Cardiology, Department of Coronary and Structural Heart Diseases email: wiktorskoti@wp.pl

Michał Świerczewski, Institute of Cardiology, Department of Coronary and Structural Heart Diseases email: swierczewski.michal@yahoo.pl

Kamil Zieliński, Institute of Cardiology, Department of Coronary and Structural Heart Diseases email: kamilziel@gmail.com

Rajmund Bobrowski, Institute of Cardiology, Department of Coronary and Structural Heart Diseases email: rajmund.bobrowski@gmail.com

Ilona Michałowska, Institute of Cardiology, Department of Coronary and Structural Heart Diseases email: imichalowska@ikard.pl

Marcin Demkow, Institute of Cardiology, Department of Coronary and Structural Heart Diseases email: mdemkow@ikard.pl

Received: 2019-12-30

Revised:

Accepted: 2019-12-30

Final review:

DOI: $10.24255 / \mathrm{hbj} / 115998$

\section{Key words:}

spontaneous coronary artery dissection, Loeys-Dietz syndrome, computed tomography

Loeys-Dietz syndrome is an autosomal dominant disorder affecting the connective tissue. It is generally characterized by aortic aneurysms, arterial tortuosity and dissections, hypertelorism, bifid/broad uvula or cleft palate and early-onset osteoarthritis. ${ }^{(1)}$ It is now estimated that spontaneous coronary artery dissection (SCAD) is the underlying cause of $1.7 \%$ to $4 \%$ of acute coronary syndromes (ACS) and accounts for $0.5 \%$ of sudden cardiac deaths. ${ }^{(2-4)}$ Furthermore, in young women $<60$ years of age, SCAD accounts for $22 \%$ to $35 \%$ of ACS presentations. ${ }^{(2,5,6)}$ It has been proposed that a mutation in transforming growth factor beta receptors 1 and 2 and SMAD3 genes and a documented arterial aneurysm or dissection should suffice to establish a diagnosis of LDS. ${ }^{(7,8)}$ A 48 -year-old woman with Loeys-Dietz syndrome with no aortic enlargement was admitted for scheduled diagnostics for examination of coronaries due to nonspecific chest pain. The 12-lead ECG recorded at rest suggested myocardial necrosis of both anterior and inferior regions of the left ventricle. Echocardiography revealed mild enlargement of the left ventricle with its hypertrophy and aneurysm of the inferior wall and apical akinesia. The ECG-gated 384-row angio-CT (SOMATOM, Siemens Healthineers, Erlangen, Germany) revealed presence of dissection of the tunica intima suggesting features of SCAD recognized along the entire lengths of proximal segments of the right coronary (RCA) and the left anterior descending artery (LAD) (Figure $1 \mathrm{a}, 1 \mathrm{~b}$ and $2 \mathrm{a}, 2 \mathrm{~b}$; respectively). Finally, digital coronarography was performed using the Siemens AXIOM (1024x1024 flat panel detector) that confirmed typical features of SCAD which did not interfere with epicardial blood and tissue blood flow (normal TIMI epicardial and myocardial blood flow) 
(Figure 3a, 3b; respectively). After initiation of the optimal medical therapy, the patient was discharged with no symptoms and was scheduled for routine angiography at 12-month follow-up, or whenever symptoms of angina pectoris reoccur. Spontaneous coronary artery dissection is a rare complication in patients with Loeys-Dietz syndrome that can appear due to malformation of the connective tissue in the lining of the coronary arteries. Missed diagnoses are caused by both visual limitations of current $\mathrm{CT}$ and lack of clinician familiarity with the condition. ${ }^{(9)}$ The $1024 \times 1024$ digital coronarography (Figure 1; 1.a, 1.b, 2.a, 2.b) is a rarely used screening method. The case highlights the importance of proper angiographic screening in patients with Loeys-Dietz syndrome, especially in young females, and proves that digital coronarography is a viable method of SCAD screening.

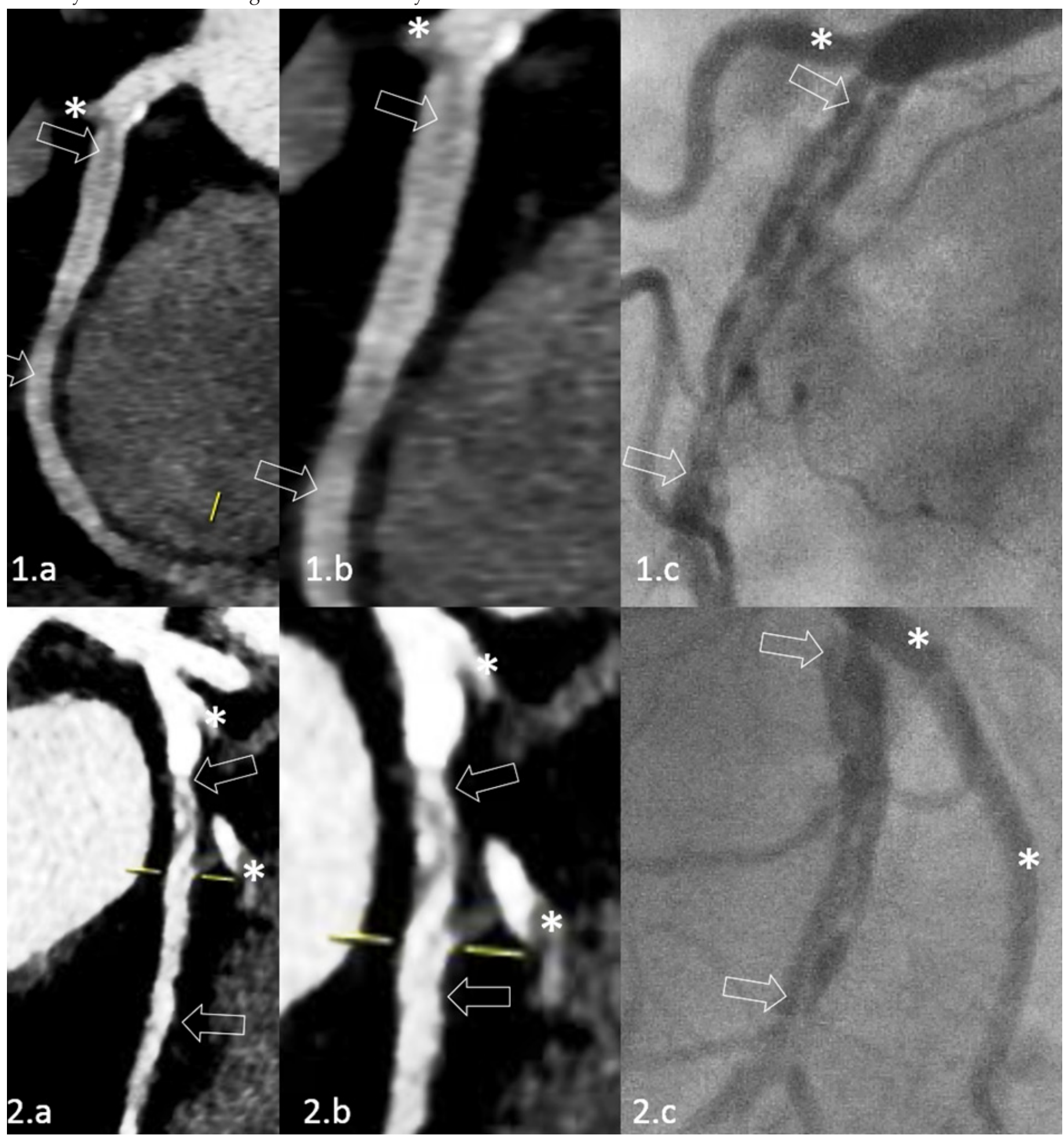

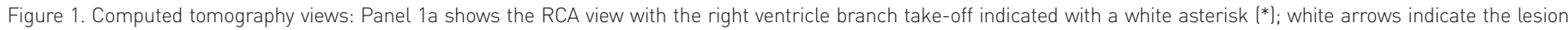

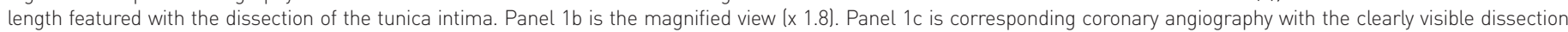

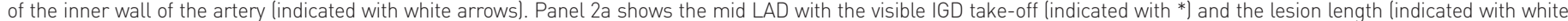
arrows) featuring typical signs of dissection of the tunica intima. Panel $2 b$ is the magnified view ( $x 1.8$ ). 


\section{References}

1. Solomonica A, Bagur R, Choudhury T, Lavi S. Familial Spontaneous Coronary Artery Dissection and theSMAD3 Mutation. Am J Cardiol. 2019 Jul 15;124(2):313-315.

2. Rashid HN, Wong DT, Wijesekera $\mathrm{H}$, et al. Incidence and characterisation of spontaneous coronary artery dissection as a cause of acute coronary syndrome: a single-centre Australian experience. Int J Cardiol 2016;202:336-8.

3. Nishiguchi T, Tanaka A, Ozak \i Y, et al. Prevalence of spontaneous coronary artery dissection in patients with acute coronary syndrome. Eur Heart J Acute Cardiovasc Care 2016;5:263-70.

4. Hill SF, Sheppard MN. Non-atherosclerotic coronary artery disease associated with sudden cardiac death. Heart 2010;96:1119-25.

5. Nakashima T, Noguchi T, Haruta S, et al.Prognostic impact of spontaneous coronary artery dissection in young female patients with acute myocardial infarction: a report from the Angina Pectoris-Myocardial Infarction Multicenter Investigators in Japan. Int J Cardiol 2016;207:341-8.

6. Saw J, Aymong E, Mancini J, Sedlak T, Starovoytov A, Ricci D. Non-atherosclerotic coronary artery disease in young women. Can J Cardiol 2014;30:814-9.

7. MacCarrick G, Black JH 3rd, Bowdin S, El-Hamamsy I, Frischmeyer- Guerrerio PA, Guerrerio AL, Sponseller PD, Loeys B, Dietz HC 3rd. Loeys-Dietz syndrome: a primer for diagnosis and management. Genet Med 2014;16:576-587.

8. Schepers D, Tortora G, Morisaki H, MacCarrick G, Lindsay M, Liang D, Mehta SG, Hague J, Verhagen J, van de Laar I, Wessels M, Detisch Y, van Haelst M, Baas A, Lichtenbelt K, Braun K, van der Linde D, Roos-Hesselink J, McGillivray G, Meester J, Maystadt I, Coucke P, El-Khoury E, Parkash S, Diness B, Risom L, Scurr I, Hilhorst-Hofstee Y, Morisaki T, Richer J, Desir J, Kempers M, Rideout AL, Horne G, Bennett C, Rahikkala E, Vandeweyer G, Alaerts M, Verstraeten A, Dietz H, Van Laer L, Loeys B. A mutation update on the LDS-associated genes TGFB2/3 and SMAD2/3. Hum Mutat 2018;39:621-634.
9. Saw J, Humphries K, Aymong E, Sedlak T, Prakash R, Starovoytov A, Mancini GBJ. Spontaneous Coronary Artery Dissection: Clinical Outcomes and Risk of Recurrence. J Am Coll Cardiol. 2017 Aug 29;70(9):11481158. 